\title{
Feeding behavior of lambs fed diets containing old man saltbush hay
}

\author{
Comportamiento ingestivo de corderos alimentados con dietas conteniendo heno de hierba-sal
}

Comportamento ingestivo de cordeiros alimentados com dietas contendo feno de erva-sal

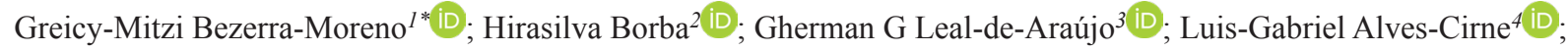 \\ Oscar Boaventura-Neto ${ }^{5}$ (D); Salete Alves-de-Moraes ${ }^{3}$ (D); Gleidson-Giordano Pinto-de-Carvalho ${ }^{6}$ (D); \\ Dorgival M de Lima-Júnior ${ }^{1}$ (D); Douglas dos-Santos-Pina ${ }^{6}$ (D).
}

\begin{abstract}
${ }^{1}$ Departamento de Zootecnia, Universidade Federal de Alagoas, Arapiraca, Alagoas, Brasil.
${ }^{2}$ Departamento de Tecnologia de Produtos de Origem Animal, Universidade Estadual Paulista, Jaboticabal, São Paulo, Brasil.

${ }^{3}$ Centro de Pesquisa Agropecuária do Trópico Semi Árido, Empresa Brasileira de Pesquisa Agropecuária, Petrolina, Bahia, Brasil.

${ }^{4}$ Instituto de Biodiversidade e Floresta, Universidade Federal do Oeste do Pará, Santarém, Pará, Brasil.

${ }^{5}$ Unidade Educacional Viçosa, Universidade Federal de Alagoas, Viçosa, Alagoas, Brasil.

${ }^{6}$ Departamento de Zootecnia, Universidade Federal da Bahia, Salvador, Bahia, Brasil.
\end{abstract}

\section{To cite this article:}

Bezerra-Moreno GM, Borba H, Leal-de-Araújo GG, Alves-Cirne LG, Boaventura-Neto O, Alves-de-Moraes S, Pinto-de-Carvalho GG, Lima-Júnior DM, dos-Santos-Pina D. Feeding behavior of lambs fed diets containing old man saltbush hay. Rev Colomb Cienc Pecu 2021; 34(4): 267-277. DOI: https://doi.org/10.17533/udea.rccp.v34n4a03

\begin{abstract}
Background: We hypothesized that a diet with old man saltbush hay used as an alternative source of nutrients could partially replace the concentrate in the feeding of feedlot lambs. Objective: This study evaluated the behavior and performance of lambs fed diets containing increasing levels of old man saltbush hay plus concentrate. Methods: Twenty-four castrated Santa Inês lambs at approximately eight months of age $(22 \pm 1.97 \mathrm{~kg})$ were confined in a randomized complete design and fed diets containing 30, 40, 50, and 60\% (dry matter: DM) of old man saltbush hay. Results: The intake of DM and neutral detergent fiber was not affected ( $>0.05)$ by the level of old man saltbush hay. Intake of mineral salt decreased $(p<0.01)$ as the proportion of old man saltbush in the diet increased. Weight gain $(\mathrm{kg})$ and feed efficiency worsened $(\mathrm{p}<0.05)$ with $40 \%$ inclusion of old man salt bush hay. The time spent on feeding and chewing increased $(p<0.05)$, while idle time was reduced $(p<0.01)$ with dietary inclusion of old man saltbush. Feed efficiency decreased $(p<0.05)$ with the inclusion of old man saltbush. Conclusion: Dietary inclusion of old man saltbush affects the feeding behavior and performance of lambs in feedlot.
\end{abstract}

Received: August 23, 2019; Accepted: September 20, 2020

*Corresponding author. Arapiraca, Alagoas, Brazil. Tel.: +55 41 98296068522. Email: greicymitzimoreno@yahoo.com.br 
Keywords: alternative feedstuff; chewing; ethology; feed efficiency; intake; feedlot; lamb; old man saltbush; rumination efficiency; sheep; weight gain.

\section{Resumen}

Antecedentes: Nuestra hipótesis consistió en que una dieta con heno de hierba-sal como fuente alternativa de nutrientes puede sustituir parcialmente el concentrado en la alimentación de corderos confinados. Objetivo: Evaluar el comportamiento ingestivo de corderos alimentados con dietas conteniendo niveles incrementales de heno de hierba-sal asociado al concentrado. Métodos: Veinticuatro corderos Santa Inés, castrados, con aproximadamente ocho meses de edad, peso corporal de $22 \pm$ $1,97 \mathrm{~kg}$, confinados, fueron distribuidos en un arreglo experimental completamente aleatorizado y alimentados con dietas conteniendo 30, 40, 50 y 60\% (materia seca: MS) de heno de hierba-sal. Resultados: El consumo de MS y fibra detergente neutra no se vió afectado $(\mathrm{p}>0,05)$ por los diferentes niveles de inclusión de hierba-sal. La ingestión de sal mineral se redujo $(\mathrm{p}<0,01)$ al incrementar la hierba-sal en la dieta. La ganancia de peso $(\mathrm{kg})$ y la eficiencia alimenticia empeoraron $(\mathrm{p}<0,05)$ con la inclusión de $40 \%$ de heno de hierba-sal. El tiempo empleado para las actividades de alimentación y masticación aumentó $(\mathrm{p}<0,05)$, mientras que el de ocio se redujo $(\mathrm{p}<0,01)$ con la inclusión de hierba-sal. La eficiencia alimenticia de la materia seca disminuyó $(\mathrm{p}<0,05)$ a medida que aumentó el nivel de inclusión de heno de hierba-sal. Conclusión: La inclusión de heno de hierba-sal en la dieta afecta el comportamiento ingestivo y el rendimiento de corderos confinados.

Palabras clave: alimento alternativo; confinamiento; cordero; eficiencia alimenticia; eficiencia de rumia; etología; ganancia de peso; hierba-sal; ingestión; masticación; ovinos.

\section{Resumo}

Antecedentes: A hipótese foi que uma dieta com o feno de erva-sal como fonte alternativa de nutrientes poderia substituir parcialmente o concentrado na alimentação de cordeiros confinados. Objetivo: Este estudo foi desenvolvido para avaliar o comportamento ingestivo de cordeiros alimentados com dietas contendo feno de erva-sal associado com o concentrado. Métodos: Vinte e quatro cordeiros Santa Inês, castrados, com aproximadamente oito meses de idade, peso corporal de $22 \pm$ $1,97 \mathrm{~kg}$, confinados, foram distribuídos em um delineamento experimental inteiramente casualizado e alimentados com dietas contendo 30, 40, 50 e 60\% (matéria seca (MS)) de feno de erva-sal. Resultados: O consumo de matéria seca e fibra em detergente neutro não foram comprometidos $(\mathrm{p}>0,05)$ pelos diferentes níveis de erva-sal. A ingestão de sal mineral reduziu $(\mathrm{p}<0,01)$ com o aumento de erva sal nas dietas. O ganho de peso e a eficiência alimentar pioraram $(\mathrm{p}<0,05)$ a partir da inclusão de $40 \%$ de feno de erva-sal na dieta dos cordeiros. O tempo despendido para as atividades de alimentação e mastigação aumentaram $(p<0,05)$, enquanto que o de ócio reduziu $(p<0,01)$ com a inclusão da erva sal nas dietas. A eficiência de alimentação da matéria seca diminuiu $(p<0,05)$ à medida que se incluiu o feno de erva-sal. Conclusão: A inclusão de feno de erva-sal na dieta afeta o comportamento ingestivo eo desempenho de cordeiros confinados.

Palavras-chave: alimento alternativo; confinamento; cordeiro; eficiência de alimentação; eficiência de ruminação; erva-sal; etologia; ganho de peso; ingestão; mastigação; ovinos. 


\section{Introduction}

Feeding is a main challenge of lamb farming in feedlot systems, in most cases due to high costs. Among the feedstuffs commonly used in sheep diets, corn and soybean meals stand out for being an excellent combination of energy and protein - components of high biological value - , but their cost is a limiting factor for using them. For this reason, research has been undertaken with alternative nutrient sources in an attempt to partially or completely replace these ingredients (Carvalho et al., 2008; Bastos et al., 2014; Cirne et al., 2014).

Old man saltbush (Atriplex nummularia Lindl.), a plant of the family Chenopodiaceae, is an Australian forage shrub that has been used in many arid and semi-arid regions of the world as an important resource in the formulation of diets for ruminants. This species is adapted to saline soils; it can be productive and used where other forage species have not survived. The crude protein (CP) content in the leaves of this plant ranges from 10 to $17 \%$ (FAO, 1996), making it an interesting option as a protein source. It also has high mineral content - 17.0 to $20.0 \%$ dry matter (DM) - and a large portion of these minerals is composed of sodium, chloride, and potassium, besides high concentrations of calcium, magnesium, phosphorus, and sulfur (Standing Committee on Agriculture, 1990), and its in vitro dry matter digestibility is around 56.7\% (Porto and Araújo, 1999). However, the metabolizable energy content of old man saltbush is approximately $1.67 \mathrm{Mcal} / \mathrm{kg} \mathrm{DM}$ (Wilson, 1994), which implies the need for supplementation with other energy sources.

Information about feeding behavior is also important, since interactions between type of feed, intake, and environment make it possible to adjust the dietary management of animals to achieve the best productivity. According to Hodgson (1990), ruminants adapt to many feeding, management, and environmental conditions, changing their feeding-behavior to attain and maintain certain level of intake compatible with their nutritional requirements.
In view of the above considerations, this study was conducted to evaluate the feeding behavior of feedlot lambs fed diets containing several inclusion levels of old man saltbush hay.

\section{Materials and Methods}

\section{Ethical considerations}

The study followed the Ethical Principles of Animal Experimentation adopted by the Brazilian College of Animal Experimentation (COBEA), and was approved by the Committee of Animal Ethics and Welfare (CEBEA) of the Faculty of Agricultural and Veterinary Sciences (FCAV) at Unesp, case no. 008403-08.

\section{Location}

The study was conducted at Embrapa Semiarid, located in Petrolina - PE, Brazil (09 $23^{\prime} 55^{\prime \prime}$ $\mathrm{S}$ latitude 40³0'03" W longitude). The climate is hot semi-arid (BSh type, according to the Köppen-Geiger climate classification), with a spring-summer rainfall regime with $577 \mathrm{~mm} /$ year average precipitation, and 58\% relative humidity. During the experiment, the maximum, minimum, and mean temperatures were 38,21 , and $29.4^{\circ} \mathrm{C}$, respectively.

\section{Animals, experimental design, and diets}

Twenty-four castrated Santa Inês lambs with an average initial weight of $22 \pm 1.97 \mathrm{~kg}$ at eight months of age were used in this experiment. The animals were identified, dewormed, vaccinated against clostridial diseases, and distributed at random into the treatments. Twenty days were used for adaptation to experimental diets and facilities. Lambs were housed in individual stalls equipped with feeders, drinkers, and salt troughs in an area covered by a shade net.

Treatments consisted of diets containing 30, 40,50 , and $60 \%$ of dry matter (DM) of old man saltbush hay associated with concentrates, at different roughage:concentrate ratios (Table 1). The concentrates were ground maze, soybean meal, and urea, and diets were calculated to be isoproteic (12\% of crude protein) and followed 
the recommendations of the National Research Council - NRC (2007) to meet the requirements of sheep with a body weight of $20 \mathrm{~kg}$, aiming at a daily weight gain of $200 \mathrm{~g} /$ animal.

The old man saltbush plants were harvested from a three-year-old field, grown under irrigation in a soil classified as a Plinthic Eutrophic Yellow Argisol (isohyperthermic Plinthustalfs in the US Soil Taxonomy). For haymaking, the plants were chopped and crushed before being exposed to the sun, laid on a cemented area, stirred twice daily, and bagged after three days of exposure, when they were dry to the touch. Leaves and branches of fine to medium thickness (approximately $1.0 \mathrm{~cm}$ ) were used for haymaking. After haying, this material was ground through a $0.8-\mathrm{mm}$ thick sieve to homogenize the concentrates and prevent animal selectivity.

\section{Chemical analysis}

Feed was supplied at 09 and 16h00, and the daily amount was controlled to allow for $20 \%$ leftovers. During the feedlot period, samples of ingredients (Table 1), feeds supplied, and leftovers were collected for laboratory analyses and determination of dry matter (DM) intake and feed efficiency (calculated as the ratio between weight gain and DM intake).

Table 1. Centesimal composition of ingredients and chemical and mineral composition of experimental diets.

\begin{tabular}{|c|c|c|c|c|}
\hline \multirow{2}{*}{ Diet composition } & \multicolumn{4}{|c|}{ Old man saltbush (g/kg, DM basis) } \\
\hline & 300 & 400 & 500 & 600 \\
\hline \multicolumn{5}{|l|}{ Ingredient } \\
\hline Old man saltbush hay & 300.0 & 400.0 & 500.0 & 600.0 \\
\hline Ground corn & 591.5 & 495.0 & 399.0 & 303.0 \\
\hline Soybean meal & 96.0 & 96.0 & 96.0 & 96.0 \\
\hline Urea & 12.5 & 9.0 & 5.0 & 1.2 \\
\hline \multicolumn{5}{|l|}{ Chemical composition } \\
\hline Dry matter & 892.1 & 891.6 & 891.5 & 890.5 \\
\hline Organic matter & 928.1 & 913.3 & 898.5 & 883.7 \\
\hline Ash & 71.9 & 86.7 & 101.5 & 116.3 \\
\hline Crude protein & 125.7 & 124.6 & 123.5 & 122.3 \\
\hline Ether extract & 37.0 & 32.9 & 28.9 & 24.8 \\
\hline Neutral detergent fiber ${ }^{1}$ & 374.7 & 414.9 & 455.3 & 495.7 \\
\hline Acid detergent fiber & 178.3 & 213.5 & 248.7 & 283.9 \\
\hline Lignin & 53.4 & 66.0 & 78.6 & 91.2 \\
\hline Total carbohydrates & 754.6 & 748.0 & 741.9 & 735.8 \\
\hline Non-fibrous carbohydrates & 436.9 & 389.1 & 341.7 & 294.2 \\
\hline Total digestible nutrients $(\mathrm{g} / \mathrm{kg})^{2}$ & 711.8 & 682.5 & 604.0 & 564.1 \\
\hline Gross energy (Mcal/kg) & 42.3 & 41.5 & 40.7 & 39.9 \\
\hline \multicolumn{5}{|l|}{ Mineral composition } \\
\hline Sodium & 18.8 & 24.9 & 31.0 & 37.1 \\
\hline Chloride & 22.8 & 30.2 & 37.8 & 45.2 \\
\hline Phosphorus & 6.2 & 6.0 & 5.8 & 5.7 \\
\hline Calcium & 3.4 & 4.1 & 4.7 & 5.4 \\
\hline Magnesium & 2.2 & 2.4 & 2.7 & 2.9 \\
\hline Potassium & 11.5 & 12.2 & 12.8 & 13.4 \\
\hline
\end{tabular}

${ }^{1}$ Corrected for ash and protein. ${ }^{2}$ Calculated according to WEISS (1999), as follows: TDN $=$ digestible $\mathrm{CP}+2.25 \times$ digestible $\mathrm{EE}+$ digestible NDFap + digestible NFC. 
The animals were weighed at the start (initial weight) and end (final weight) of the experiment to calculate weight gain $(\mathrm{kg})$.

Samples were pre-dried in a forced-air oven at $55{ }^{\circ} \mathrm{C}$ for $72 \mathrm{~h}$ and then ground through a Wiley mill with $1-\mathrm{mm}$ sieves to determine dry matter (DM), organic matter (OM), crude protein $(\mathrm{CP})$, and mineral matter (MM) contents according to methodologies described by Silva and Queiroz (2002). Ether extract (EE) was determined in an Ankom XT-10 Extraction System (Ankom Technology, Macedon, NY, USA). Neutral detergent fiber corrected for ash and protein (NDFap), acid detergent fiber (NADF), and lignin were obtained following Van Soest (1994), using non-woven fabric (TNT - $100 \mathrm{~g} / \mathrm{m} 2$ ). Total carbohydrates (TC) were obtained by the following equation: $100-(\% \mathrm{CP}$ $+\% \mathrm{EE}+\% \mathrm{MM})$, and non-fibrous carbohydrates (NFC) were calculated as the difference between TC and NDFap, both proposed by Sniffen et al. (1992). Total digestible nutrients were calculated according to Weiss (1999), as follows TDN $=$ digestible $\mathrm{CP}+2.25 \times$ digestible $\mathrm{EE}+$ digestible NDFap + digestible NFC. After nitric-perchloric digestion of samples of feed supplied, phosphorus, chlorine, sodium, calcium, magnesium, and potassium were also determined. Chlorine and phosphorus were determined by spectrophotometry, and the others were obtained by atomic absorption.

\section{Nutrient intake}

The intake of nutrient components was calculated as the difference between the amounts of that component present in the feed and in the orts, as follows: Nutrient intake $(\mathrm{kg})=$ Nutrient in feed-Nutrient in orts.

\section{Ingestive behavior}

The experiment lasted 80 days, the first 20 of which were used for adaptation of animals to diet and environment, and the remaining days for the performance trial. The feeding behavior was determined in three $24-\mathrm{h}$ periods with intervals of approximately 20 days, corresponding to the start, middle, and end of the experimental period.
To record the time spent feeding, ruminating, and idle, the animals were observed at every $10 \mathrm{~min}$ by trained observers. Each observation/ observer round lasted about $20 \mathrm{~s}$ (six observers; 4 animals/observer) who switched turns (change of observers at every $4 \mathrm{~h} ; 12$ observers in total) and were positioned strategically so as not to disturb the animals. Observations started at 08h00 and ended at the same time on the next day, totaling $24 \mathrm{~h}$ of observation. For data collection during nocturnal observations, the environment was maintained under artificial illumination.

On the same day, the number of rumination chews per cud (n/cud) was counted and the time taken to ruminate each cud ( $\mathrm{s} / \mathrm{cud}$ ) was measured using a digital timer. To obtain the average number of chews and time, three ruminal cuds were observed in four periods of the day $(06 \mathrm{~h} 00$ to $07 \mathrm{~h} 00 ; 12 \mathrm{~h} 00$ to $13 \mathrm{~h} 00 ; 18 \mathrm{~h} 00$ to $19 \mathrm{~h} 00$; and $00 \mathrm{~h} 00$ to $01 \mathrm{~h} 00$ ), following the methodology described by Bürguer et al. (2000), counting the time and number of chews for every ruminal cud per animal.

To estimate the intakes of dry matter (DM) and neutral detergent fiber (NDF), and the feeding-, rumination-, and idleness-related behavioral variables feeding and rumination time ( $\mathrm{min} / \mathrm{kg}$ of DM and NDF), feed and rumination efficiencies (g DM and NDF/h), ruminal cud chewing (h/ day, n/cud and n/day), number (day) and time (min) spent per period (feeding, rumination, and idleness), DM and NDF intakes (g) per meal, rumination (cuds/day, chews/cud, and $\mathrm{g}$ of DM and NDF/cud), and total chewing times ( $\mathrm{min} / \mathrm{kg}$ of DM and NDF), we considered the voluntary intakes of DM and NDF on the 20th, 40th, and 60th days of the experiment.

The daily number of cuds was obtained by dividing the total rumination time ( $\mathrm{min}$ ) by the average time taken to ruminate one cud. Dry matter and NDF concentrations in each ruminal cud $(\mathrm{g})$ were obtained by dividing the amounts of DM and NDF consumed $(\mathrm{g} / \mathrm{d})$ in $24 \mathrm{~h}$ by the number of daily cuds ruminated. Feed and rumination efficiency were obtained as follows: 
FEDM $=$ DMI/FT; and FENDF $=$ NDFI/FT, where FEDM $(\mathrm{kg} \mathrm{DM} / \mathrm{h})=$ feed efficiency in dry matter; DMI (kg DM/day) = dry matter intake; FT (min/day) = feeding time; FENDF $(\mathrm{kg}$ $\mathrm{NDF} / \mathrm{h})=$ feed efficiency in neutral detergent fiber; and NDFI ( $\mathrm{kg} \mathrm{NDF} /$ day) = neutral detergent fiber intake.

$\mathrm{REDM}=\mathrm{DMI} / \mathrm{RT}$; and $\mathrm{RENDF}=\mathrm{NDFI} / \mathrm{RT}$,

where: REDM $(\mathrm{kg} \mathrm{DM} / \mathrm{h})=$ rumination efficiency in dry matter; RT (min/day) = rumination time; and RENDF ( $\mathrm{kg} \mathrm{NDF} / \mathrm{h})=$ rumination efficiency in neutral detergent fiber.

$$
\mathrm{TCT}=\mathrm{FT}+\mathrm{RT},
$$

where TCT $(\mathrm{min} /$ day $)=$ total chewing time.

These and other variables obtained in this study were determined following the methodology described by Polli et al. (1996) and Bürguer et al. (2000).

\section{Statistical analysis}

A randomized complete design with four treatments and six replicates was adopted. Results were evaluated by statistical analyses, in which the degrees of freedom of treatments were decomposed in orthogonal polynomial contrasts to evaluate the linear or quadratic effects, according to the inclusion of old man saltbush hay. The regression model was fitted based on significance of contrasts considering $5 \%$ of probability to Type I error. The analyses were performed using SISVAR statistical software (Ferreira, 2011) according to the following statistical model:

$$
\text { yij }=\mu+t i+e i j,
$$

where: $y i j=$ observed value of treatment $i$ in the repetition $\mathrm{j} ; \mu=$ overall mean; $\mathrm{t} i=$ inclusion level of old man saltbush ( $i=30,40,50$ e $60 \%$ ), and $\mathrm{eij}=$ random error associated with each observation.

\section{Results}

Inclusion of old man saltbush in the lamb diets did not affect $(p>0.05)$ intake, except for mineral salt, which decreased $(p<0.01)$ as the inclusion level of old man saltbush in the diets increased (Table 2).

Weight gain and feed efficiency decreased $(p<0.01)$ (Table 3$)$ as the concentration of old man saltbush in the diet increased (Table 3 ).

Behavioral activities were influenced $(p<0.05)$ by the addition of old man saltbush to the diet; every $1 \%$ increase in the amount of ingredient added led to an increase of 0.32 and $3.60 \mathrm{~min} /$ day spent on feeding and chewing activities, respectively, and 0.60 $\mathrm{min} /$ day reduction of idle behavior (Table 3 ). Total chewing time ( $\mathrm{min} /$ day) also increased $(p<0.01)$ as feeding time increased, because total chewing time is calculated as the sum of the times spent feeding and ruminating in 24 $\mathrm{h}$, which further increased $(\mathrm{p}<0.01)$ chewing time, expressed as $\mathrm{min} / \mathrm{kg}$ DM (Table 3).

Feed efficiency $(\mathrm{gDM} / \mathrm{h})$ decreased $(\mathrm{p}<0.01)$, with every $1 \%$ increase in the percentage of old man saltbush, leading to a reduction of $41.53 \mathrm{~g} / \mathrm{h}$ in the DM fraction (Table 4).

Table 2. Intakes of dry matter $(\mathrm{kg})$, neutral detergent fiber $(\mathrm{kg})$, mineral salt $(\mathrm{g})$, and water (l) by lambs fed diets

\begin{tabular}{|c|c|c|c|c|c|c|c|}
\hline \multirow{2}{*}{ Item } & \multicolumn{4}{|c|}{ Old man saltbush (g/kg) } & \multicolumn{2}{|c|}{ p-value ${ }^{1}$} & \multirow{2}{*}{ CV (\%) } \\
\hline & 300 & 400 & 500 & 600 & $\mathbf{L}$ & $\mathbf{Q}$ & \\
\hline \multicolumn{8}{|l|}{ Intake in $24 \mathrm{~h}$} \\
\hline Dry matter & 1.214 & 1.277 & 1.230 & 1.156 & 0.590 & 0.455 & 18.17 \\
\hline Neutral detergent fiber & 0.494 & 0.560 & 0.587 & 0.585 & 0.139 & 0.439 & 19.06 \\
\hline Mineral salt ${ }^{2}$ & 6.75 & 5.52 & 3.75 & 3.25 & 0.008 & 0.711 & 48.46 \\
\hline Water & 3.85 & 4.80 & 4.61 & 4.49 & 0.323 & 0.165 & 21.03 \\
\hline
\end{tabular}
containing increasing levels of old man saltbush.

$\mathrm{CV}$, coefficient of variation; ${ }^{1}$ Effect: $\mathrm{L}$, linear; Q, quadratic; and ${ }^{2} \mathrm{Y}=10.34-0.12 \mathrm{x} . \mathrm{R}^{2}=0.96$. 
Table 3. Average weight gain (WG), feed efficiency (FE), and time spent feeding, ruminating, chewing, and idle in $24 \mathrm{~h}$ by lambs fed diets containing increasing levels of old man saltbush.

\begin{tabular}{|c|c|c|c|c|c|c|c|}
\hline \multirow{2}{*}{ Variable } & \multicolumn{4}{|c|}{ Old man saltbush (g/kg) } & \multicolumn{2}{|c|}{ p-value ${ }^{1}$} & \multirow{2}{*}{ CV $(\%)$} \\
\hline & 300 & 400 & 500 & 600 & $\mathbf{L}$ & $\mathbf{Q}$ & \\
\hline \multicolumn{8}{|l|}{ Performance } \\
\hline Weight gain $(\mathrm{kg})^{2}$ & 13.83 & 12.47 & 10.69 & 8.91 & 0.005 & 0.635 & 32.48 \\
\hline $\mathrm{FE}(\mathrm{kg} \mathrm{WG} / \mathrm{kg} \mathrm{DM})^{3}$ & 0.177 & 0.160 & 0.145 & 0.127 & 0.004 & 0.962 & 21.93 \\
\hline \multicolumn{8}{|l|}{ Feeding } \\
\hline $\min / \mathrm{d}^{4}$ & 191.22 & 190.62 & 219.60 & 245.40 & 0.036 & 0.501 & 22.23 \\
\hline $\mathrm{min} / \mathrm{kg} \mathrm{DM}^{5}$ & 143.87 & 167.68 & 191.49 & 215.29 & 0.016 & 0.300 & 27.70 \\
\hline $\mathrm{min} / \mathrm{kg}$ NDF & 356.90 & 379.49 & 402.08 & 424.67 & 0.269 & 0.302 & 27.89 \\
\hline \multicolumn{8}{|l|}{ Rumination } \\
\hline $\min / \mathrm{d}$ & 325.80 & 351.60 & 362.40 & 378.00 & 0.142 & 0.837 & 16.98 \\
\hline $\min / \mathrm{kg} \mathrm{DM}$ & 270.00 & 276.80 & 207.35 & 341.87 & 0.071 & 0.637 & 23.72 \\
\hline $\mathrm{min} / \mathrm{kg}$ NDF & 662.00 & 630.75 & 644.70 & 674.04 & 0.854 & 0.621 & 22.66 \\
\hline \multicolumn{8}{|l|}{ Chewing } \\
\hline $\min /$ day $^{6}$ & 517.20 & 541.80 & 582.60 & 624.00 & 0.003 & 0.741 & 10.42 \\
\hline $\mathrm{min} / \mathrm{kg} \mathrm{DM}^{7}$ & 425.86 & 430.09 & 491.67 & 566.75 & 0.009 & 0.679 & 19.27 \\
\hline $\mathrm{min} / \mathrm{kg}$ NDF & 1.045 & 977.70 & 1.032 & 1.119 & 0.446 & 0.341 & 18.63 \\
\hline $\mathrm{n} /$ cud & 76.71 & 80.21 & 70.84 & 75.17 & 0.497 & 0.928 & 14.66 \\
\hline s/cud & 48.93 & 59.03 & 51.49 & 53.81 & 0.602 & 0.209 & 13.79 \\
\hline n/day & 30.885 & 28.565 & 29.948 & 31.828 & 0.674 & 0.353 & 17.87 \\
\hline \multicolumn{8}{|l|}{ Idle } \\
\hline $\min / \mathrm{d}$ & 922.68 & 897.60 & 857.10 & 816.00 & 0.003 & 0.741 & 6.76 \\
\hline
\end{tabular}

$\mathrm{CV}$, coefficient of variation; ${ }^{1}$ Effect: $\mathrm{L}$, linear; $\mathrm{Q}$, quadratic; ${ }^{2} \mathrm{Y}=19.58-0.177750 \mathrm{x}$. R2 $=0.96 ;{ }^{3} \mathrm{Y}=0.226788-0.001649 \mathrm{x}$. $\mathrm{R} 2=0.99 ;{ }^{4} \mathrm{Y}=120.070833+23.807167 \mathrm{x} . \mathrm{R} 2=0.85 ;{ }^{5} \mathrm{Y}=404.279167+3.605500 \mathrm{x} . \mathrm{R} 2=0.98 ;{ }^{6} \mathrm{Y}=357.533333+48.424667 \mathrm{x}$. $\mathrm{R} 2=0.89 ;$ and ${ }^{7} \mathrm{Y}=16.059167-0.601167 \mathrm{x} . \mathrm{R} 2=0.98$.

Table 4. Feed and rumination efficiencies of lambs fed diets containing increasing levels of old man saltbush.

\begin{tabular}{|c|c|c|c|c|c|c|c|}
\hline \multirow{2}{*}{ Variable } & \multicolumn{4}{|c|}{ Old man saltbush (g/kg) } & \multicolumn{2}{|c|}{ p-value ${ }^{1}$} & \multirow{2}{*}{ CV $(\%)$} \\
\hline & 300 & 400 & 500 & 600 & $\mathbf{L}$ & $\mathbf{Q}$ & \\
\hline \multicolumn{8}{|l|}{ Feed efficiency } \\
\hline $\mathrm{g} \mathrm{DM} / \mathrm{h}^{2}$ & 399.38 & 419.78 & 352.98 & 283.19 & 0.037 & 0.290 & 27.98 \\
\hline g NDF/h & 163.19 & 183.48 & 169.01 & 143.57 & 0.390 & 0.234 & 27.73 \\
\hline \multicolumn{8}{|c|}{ Rumination efficiency } \\
\hline Cuds (n/day) & 407.53 & 357.74 & 428.20 & 441.79 & 0.326 & 0.419 & 23.06 \\
\hline $\mathrm{g} \mathrm{DM} / \mathrm{cud}$ & 3.06 & 3.64 & 2.91 & 2.76 & 0.225 & 0.229 & 23.25 \\
\hline g NDF/cud & 1.24 & 1.60 & 1.38 & 1.39 & 0.711 & 0.197 & 22.84 \\
\hline $\mathrm{g} \mathrm{DM} / \mathrm{h}$ & 224.28 & 221.41 & 207.44 & 185.67 & 0.091 & 0.570 & 19.12 \\
\hline $\mathrm{g} \mathrm{NDF} / \mathrm{h}$ & 91.51 & 97.47 & 99.03 & 93.75 & 0.813 & 0.475 & 19.86 \\
\hline
\end{tabular}

$\mathrm{CV}$, coefficient of variation; DM, dry matter; NDF, neutral detergent fiber; ${ }^{1}$ Effect: L, linear; $\mathrm{Q}$, quadratic; and ${ }^{2} \mathrm{Y}=467.678333-41.536167 x . \mathrm{R}^{2}=0.78$. 
This was a response to longer feeding time, since feed efficiency, expressed as g DM/h, was obtained by dividing average daily DM intake by total time spent feeding in $24 \mathrm{~h}$. In this study, DM intake (kg/day) was similar among diets (Table 2), which also explains the result obtained for efficiency, which is directly related to intake expressed in $\mathrm{kg} / \mathrm{day}$. The number of cuds ruminated (n/day) and the chewing time per cud (s) were not affected $(p>0.05)$ by the addition of old man saltbush (Tables 3 and 4).

Rumination activity, expressed as g of DM and NDF/h (209.70 and $95.44 \mathrm{~g} / \mathrm{h}$, respectively), did not change $(p>0.05)$. Although the dietary NDF content changed with inclusion of old man saltbush, the maximum difference observed between the levels of this fraction $(12.38 \%)$ in the diets with 0 and $60 \% \mathrm{DM}$ inclusion were not sufficient to affect rumination activity.

No difference was observed $(p<0.05)$ for number of periods and time spent per feeding (13.91 meals and $15.79 \mathrm{~min} / \mathrm{meal}$, respectively), rumination (20.47 rumination bouts and $21.24 \mathrm{~min} /$ rumination bout, respectively) and idleness (25.74 idle periods and $34.39 \mathrm{~min} /$ idle period, respectively) period, or for DM and NDF intakes, expressed as g/meal 92.02 and $41.97 \mathrm{~g} / \mathrm{meal}$, respectively) (Table 5).

\section{Discussion}

No alteration was observed in DM intake, likely because the higher NDF contents, -derived from the old man saltbush- did not influence the limitation of intake; moreover, water intake in all treatments was within normal values. The rumen fill effect is caused mainly by the fibrous fraction of the feed, based on the NDF of the evaluated forage (Madsen et al., 1997).

Despite the lack of alterations in DM and NF intakes, fiber quality worsened with increase in NDF, ADF, and lignin contents (Table 1), which might have required more from animals in the chewing process and consequently during digestion. Additionally, this might have contributed to the longer time spent feeding. As stated by Van Soest (1994), lignin is considered the main factor limiting digestibility.

Mineral salt intake probably decreased as a result of high sodium content in the diet. An increase in NDF and sodium concentrations in the diet (Table 1) was also expected to increase the intake of DM and water, respectively.

Although daily weight gain decreased as old man saltbush increased in the diet, the values found in the treatment with 30 (193.41 g /day)

Table 5. Number of periods and time spent per feeding, rumination, and idle periods, and intakes of DM and NDF per meal by lambs fed diets containing increasing levels of old man saltbush.

\begin{tabular}{|c|c|c|c|c|c|c|c|}
\hline \multirow{2}{*}{ Variable } & \multicolumn{4}{|c|}{ Old man saltbush (g/kg) } & \multicolumn{2}{|c|}{ p-value ${ }^{1}$} & \multirow{2}{*}{ CV (\%) } \\
\hline & 300 & 400 & 500 & 600 & $\mathbf{L}$ & $\mathbf{Q}$ & \\
\hline \multicolumn{8}{|l|}{ Number of periods (n/day) } \\
\hline Feeding (meals) & 13.56 & 13.80 & 14.03 & 14.26 & 0.650 & 0.157 & 19.96 \\
\hline Ruminating & 19.68 & 20.23 & 20.68 & 21.29 & 0.883 & 0.663 & 21.42 \\
\hline Idle & 25.35 & 25.61 & 25.88 & 26.15 & 0.582 & 0.075 & 10.14 \\
\hline \multicolumn{8}{|l|}{ Time spent (min) } \\
\hline Feeding & 19.05 & 20.51 & 21.98 & 23.44 & 0.108 & 0.424 & 22.46 \\
\hline Ruminating & 37.11 & 35.30 & 33.49 & 31.69 & 0.075 & 0.220 & 15.38 \\
\hline Idle & 224.28 & 221.41 & 207.44 & 185.67 & 0.091 & 0.570 & 19.12 \\
\hline \multicolumn{8}{|l|}{ Intake per meal (g) } \\
\hline Dry matter & 95.15 & 93.07 & 90.98 & 88.90 & 0.704 & 0.686 & 32.15 \\
\hline Neutral detergent fiber & 38.68 & 40.87 & 43.07 & 45.26 & 0.391 & 0.740 & 32.68 \\
\hline
\end{tabular}

$\mathrm{CV}$, coefficient of variation; and ${ }^{1}$ Effect: L, linear; Q, quadratic. 
and 40\% (181.81 g/day) old man saltbush are close to that recommended by the NRC (2007), suggesting that this forage could be used as an alternative feed for feedlot sheep in regions with food shortage.

Alterations in the time spent feeding, ruminating, and idle have been commonly observed in studies in which diets varied in fiber content (Macedo et al., 2007; Mendes et al., 2010).

Fiber content, especially NDF, influences the time spent consuming and ruminating (Colenbrander, 1991), because the need for chewing is related to the amount of indigestible or not highly digestible material consumed and the resistance of the material against particle size reduction (Fisher et al., 1998). In the present study, although old man saltbush was the only roughage component in the total diet, with different roughage:concentrate ratios, the experimental diets had the same particle size, which may explain the lack of effects on rumination activity (Bastos et al., 2014).

The number of cuds ruminated per day NRC (2007) depends on the rumination time and the time taken to ruminate each cud. The fact that there were no variations in these times explains the similar NRC among the animals on the treatments. This assumption was verified by Bastos et al. (2014) and Carvalho et al. (2006), who evaluated the feeding behavior of lambs fed diets containing soybean hulls replacing corn, and the feeding behavior of Santa Inês sheep in feedlot receiving diets containing cocoa meal or palm kernel cake replacing the concentrate, respectively, and found no changes in the number of cuds ruminated (n/day) or chewing time per cud (s).

Likewise, rumination efficiency, expressed in $\mathrm{g} \mathrm{DM}$ and NDF/cud (3.09 and $1.40 \mathrm{~g} / \mathrm{cud}$, respectively), was not influenced $(p>0.05)$ by inclusion of old man saltbush in the diet (Table 4). This response may be attributed to the similar intakes of DM and NDF, and the NRC/day, since the amount of DM and NDF per cud is obtained by dividing the average daily intakes of DM and
NDF by NRC/day. This hypothesis was verified in the study of Cirne et al. (2014), who evaluated the feeding behavior of feedlot lambs fed diets containing mulberry hay replacing a concentrate based on ground corn and soy.

The inclusion of old man saltbush in the diet does not affect the discretization of time series in sheep under the feeding conditions established in this experiment (Table 5). This finding is corroborated by Cirne et al. (2014).

In conclusion, the inclusion of old man saltbush into the diet affects the feeding behavior and performance of feedlot lambs.

\section{Declarations}

\section{Conflicts of interest}

The authors declare they have no conflicts of interest with regard to the work presented in this report.

\section{Funding}

The authors gratefully acknowledge funding from the Brazilian Development Bank(BNDES), São Paulo Research Foundation (FAPESP) and CNPq for the scholarship.

\section{Author contribution}

Greicy MB Moreno designed the study, collected and analysed the data, drafted and revised the manuscript. Hirasilva Borba and Gherman GLAraújo designed the study, analysed the data and revised the manuscript. Luis Gabriel A Cirne, Gleidson GP Carvalho and Douglas S Pina contributed in the statistical analysis and revised the manuscript. Oscar Boaventura Neto and Salete A Moraes contributed in the chemical analysis and revised the manuscript. Dorgival $\mathrm{M}$ Lima Júnior revised the manuscript.

\section{References}

Bastos MPV, Carvalho GGP, Pires AJV, Silva RRS, Eustáquio Filho A, Santos EJ, Chagas DMT, Barroso DS, Abreu Filho G. Ingestive behavior and nitrogen balance of confined Santa Ines 
lambs fed diets containing soybean hulls. AsianAustralasian J Anim Sci 2014; 27(1): 24-29. DOI: https://doi.org/10.5713/ajas.2013.13076

Bürger PJ, Pereira JC, Queiroz AC, Silva JFC, Valadares Filho SC, Cecon PR, Casali ADP. Ingestive Behavior in Holstein calves fed diets with different concentrate levels. Rev Bras Zootec 2000; 29(1): 236-242. DOI: https://doi.org/10.1590/S1516-35982000000100031

Carvalho GGP, Pires AJV, Silva RR, Ribeiro LSO, Chagas DMT. Ingestive behavior of Santa Inês sheep fed diets with cocoa meal. Rev Bras Zootec 2008; 37(4): 660-665. DOI: https://doi.org/10.1590/S1516-35982008000400011

Carvalho GGP, Pires AJV, Silva RR, Veloso CM, Silva HGO. Ingestive behaviour of sheep fed with ammoniated or non-ammoniated elephantgrass silage and agro industrial by-products. Rev Bras Zootec 2006; 35(4 suppl): 1805-1812. DOI: https://doi.org/10.1590/S1516-35982006000600031

Cirne LGA, Silva Sobrinho AG, Santana VT, Silva FU, Lima NLL, Oliveira EA, Carvalho GGP, Zeola NMBL, Takahashi R. 2014. Feeding behavior of lambs fed with diets containing mulberry hay. Semin Ciências Agrárias 2014; 35(2): 1051-1060. DOI: https://doi.org/10.5433/1679-0359.2014v35n2p1051

Colenbrander VF, Noller CH, Grant RJ. Effect of fiber content and particle size of alfalfa silage on performance and chewing behavior. J Dairy Sci 1991; 74(8): 2681-2690.

Ferreira DF. Sisvar: a computer statistical analysis system. Ciên Agrotec 2011; 35(6): 1039-1042. DOI: http://dx.doi.org/10.1590/ $\underline{\text { S1413-70542011000600001 }}$

Food and Agricultural Organization. Atriplex nummularia Lindl.: una especie pionera para las zonas aridas de Chile. Proceedings of the 10th Oficina Regional de la Fao para América Latina y el Caribe; 1996; Santiago: FAO; 1996.

Fischer V, Deswysen AG, Amouche EH, Duttilleul P, Lobato JFP. Effects of Grazing Pressure on Nycterohemeral Ingestive Behavior
Patterns of Sheep on Pasture. Rev Bras Zootec 1998; 27(1): 164-170.

Hodgson J. Grazing management: science into practice. Inglaterra: Longman Handbooks in Agriculture; 1990.

Macedo CAB, Mizubuti IY, Moreira FB, Pereira S, Ribeiro ELA, Rocha MA, Ramos BMO, Mori RM, Pinto AP, Alves TC, Casimiro TR. Ingestive behaviour of sheep fed with different levels of fresh orange pulp replacing sorghum silage in the diet. Rev Bras Zootec 2007; 36(6): 1910-1916. DOI: http://dx.doi.org/10.1590/S1516-35982007000800027

Madsen J, Hvelplund T, Weisbjerg MR. Appropriate methods for evaluation of tropical feeds for ruminants. Anim Feed Sci Technol 1997; 69(1-3): 53-66.

Mendes CQ, Turino VF, Susin I, Pires AV, Morais JB, Gentil RS. Lamb feeding behavior and nutrient digestibility of high concentrate diets with different neutral detergent fiber sources. Rev Bras Zootec. 2010; 39(3): 594-600. DOI: http://dx.doi.org/10.1590/S1516-35982010000300019

National Research Council. Nutrient Requirements of Small Ruminants. 7th ed. Washington (DC): National Academy Press; 2007.

Polli VA, Restle J, Senna DB, Almeida SRS. Aspectos relativos à ruminação de bovinos e bubalinos em regime de confinamento. Rev Bras Zootec 1996; 25(5): 987-993.

Porto ERE, Araújo GGL. Erva-sal (Atriplex nummularia). Petrolina: EMBRAPA Semiarid; 1999.

Silva DJ, Queiroz AC. Análise de alimentos: métodos químicos e biológicos. 3th ed. Viçosa: UFV; 2002.

Sniffen CJ, O.Connor JD, Van Soest PJ, Fox DG, Russell JB. A net carbohydrate and protein system for evaluating catlle diets: II. Carbohydrate and protein availability. J Anim Sci 1992; 70(11): 3562-3577. 
Standing Committee on Agriculture. Feeding Standards for Australian Livestock. Melbourne: CSIRO Publications; 1990.

Van Soest PJ. Nutritional ecology of the ruminant. 2th ed. Ithaca: Cornell University Press; 1994.

Weiss WP. Energy prediction equations for ruminant feeds. Proceedings of the 61th Cornell
Nutrition Conference for Feed Manufacturers; 1999; Ithaca: Cornell University; 1999.

Wilson AD. Utilisation of halophytes by livestock: an overview. Proceedings of the 3th National Workshop on Productive Use of Saline Land; 1994; Canberra: Murray-Darling Basin Commission and Salt Action; 1994. 